\title{
Thermodynamic modeling of aqueous migration of chemical elements in irrigation water
}

\author{
Evgeniya Soldatova ${ }^{1,}$, Evgeniya Sidkina ${ }^{1}$, and Zhanxue Sun $^{2}$ \\ ${ }^{1}$ Vernadsky Institute of Geochemistry and Analytical Chemistry of Russian Academy of Sciences, \\ 119991, 19 Kosygina st., Moscow, Russia \\ ${ }^{2}$ East China University of Technology, 330013 Guanglan Avenue 418, Nanchang, China
}

\begin{abstract}
Research of migration forms in irrigation water of flooded fields contributes to understanding geochemical barrier formation and functioning. It can improve pollution and nutrification control in the soil-water-plant system since geochemical barriers promote concentrating chemical elements at different depths of a soil cross-section. The research aimed to simulate the aqueous migration of chemical elements and their precipitation in the flooded rice fields' irrigation water to determine the potential of removing them from the solution at the sorption geochemical barrier. The samples of irrigation water were taken after harvesting in the Poyang Lake basin (China) and analyzed with a standard set of methods for natural water, including ICP-MS and ICP-AES. To assess the migration forms, the $\mathrm{HCh}$ software package was used. The thermodynamic values database was supplemented with free energies of formation of metal complexes with fulvic and humic acids for standard conditions. Modeling has shown that most of the considered chemical elements migrate in positively charging simple ions. The main agents of complexation with humic substances are $\mathrm{Fe}$, $\mathrm{Ca}$, and $\mathrm{U}$. Kaolinite potentially precipitates from the irrigation water. Results show that sorption of positively charged simple ions and $\mathrm{MoO}_{4}{ }^{2-}$ on clay minerals should be under special attention.
\end{abstract}

\section{Introduction}

Modern approaches to geochemical data processing, particularly thermodynamic modeling, help to thoroughly study natural-anthropogenic ecosystems as agricultural landscapes. Research of migration forms in irrigation water of flooded fields contributes to understanding geochemical barrier formation and functioning. It can improve pollution and nutrification control in the soil-water-plant system since geochemical barriers promote concentrating chemical elements at different depths of a soil cross-section [1, 2]. In the current article, thermodynamic modeling of aqueous migration of chemical elements in irrigation water has been performed, paying attention to studying metal ability to form complexes with humic and fulvic acids. This option is connected with humic substances widespread among organic compounds in natural water and the significance of organic matter in agricultural ecosystems. The presented part of the research aimed to simulate the migration

* Corresponding author: sea@geokhi.ru 
forms of chemical elements and their precipitation in irrigation water to determine the potential of removing them from the solution at the sorption geochemical barrier.

Irrigation water was sampled in October-November 2019 in the northern part of Jiangxi Province (People's Republic of China) within flooded rice fields in the Ganjiang River basin (Fig. 1). The sampling period corresponds to the end of the agricultural season (after harvesting). For a comparative analysis, we also give a result of migration form modeling for natural wetland water. These samples were taken in the Nanjishan Wetland Nature Reserve, which is part of Poyang Lake wetland.

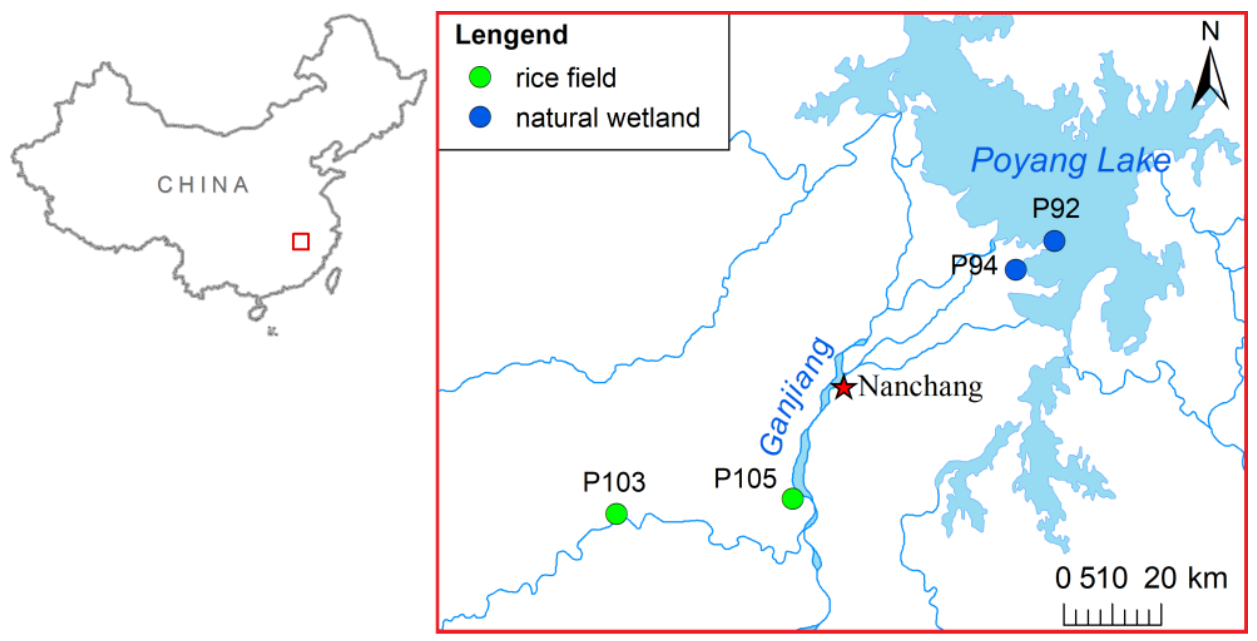

Fig. 1. Scheme of the location of the study area and the sampling points

\section{Methodology}

\subsection{Sampling procedure and chemical analysis of water samples}

Water samples for chemical analysis of major components and dissolved organic carbon (DOC) were taken in 0.5 -L plastic bottles, which were precleaned several times with the sampling water. Samples for trace element analysis were filtered through a PES syringe filter with $0.45 \mu \mathrm{m}$ pore size into $15-\mathrm{mL}$ sterile plastic tubes and acidified with $0.45 \mathrm{~mL} \mathrm{HNO}_{3}$ of high purity.

Analysis of physicochemical parameters of water was carried out in the Chemical Department (Lomonosov Moscow State University, Russia), the Laboratory of Research Methods and Analysis of Substances and Materials (Institute of Geochemistry and Analytical Chemistry, Moscow, Russia), and the Research Laboratory for Hydrogeochemistry (Tomsk Polytechnic University, Russia) by titrimetry, ion chromatography, inductively coupled plasma atomic emission spectrometry, and inductively coupled plasma mass spectrometry, and high-temperature oxidation. The content of fulvic acids (FA) and humic acids (HA) was determined by the method proposed by Krainov et al. [3], assuming that the content of FA and HA in natural water has a ratio of $9: 1$, and the DOC content in the molecule is $40 \%$ for FA and $70 \%$ for HA.

\subsection{Thermodynamic model}

To assess the migration forms, the HCh software package [4] was used. The mean statistical values of the molecular weights of HA and FA (40 000 for HA, 5000 for FA [3]) were taken 
to calculate their molal concentrations. The thermodynamic values database was supplemented with free energies of formation of metal complexes with HA and FA at standard conditions $(298.15 \mathrm{~K}, 1$ bar). The free energies were calculated using the effective stability constants (pK). Humic substances (HA, FA) were considered as indestructible independent elements and inputted as negatively charged ions $-\mathrm{HA}^{-}$and $\mathrm{FA}^{2-}$. Their free energy of formation under standard conditions was taken to be zero. The free energies of organomineral complex formation were calculated as follows:

$$
\Delta G_{f M e A}^{0 *}=\Delta G_{f M e^{m+}}^{0}-R T \ln (p K),
$$

where $\Delta G_{f M e A}^{0 *}-$ free energy of complex formation with an organic anion, $\Delta G_{f M e^{m+}}^{0}-$ free energy of metal ion, $R$ - gas contact, $T$ - temperature $(298.15 \mathrm{~K}), p K$ - effective stability constants. Selecting pK of the metal complexes with HA and FA, we considered the material from which humic substances were isolated and the $\mathrm{pH}$ of the experiment. The stability constants of the organomineral complexes are given in Table 1.

Table 1. Effective stability constants of metal complexes with humic and fulvic acids

\begin{tabular}{|c|c|c|c|c|c|c|c|c|}
\hline Ion & $\mathrm{pK}$ & Reference & Ion & $\mathrm{pK}$ & Reference & Ion & $\mathrm{pK}$ & Reference \\
\hline $\mathrm{CaFA}^{0}$ & 3.64 & {$[5]$} & $\mathrm{Fe}(\mathrm{HA})_{3}{ }^{0}$ & 10.52 & {$[6]$} & $\mathrm{CdFA}^{0}$ & 4.57 & {$[7]$} \\
\hline $\mathrm{CaHA}^{+}$ & 3.83 & {$[7]$} & $\mathrm{CoFA}$ & 4.51 & {$[7]$} & $\mathrm{CdHA}^{+}$ & 5.04 & {$[8]$} \\
\hline $\mathrm{MgFA}^{0}$ & 3.81 & {$[7]$} & $\mathrm{Co}(\mathrm{HA})_{2}{ }^{0}$ & 5.44 & {$[6]$} & $\mathrm{Cd}(\mathrm{HA})_{2}{ }^{0}$ & 6.90 & {$[9]$} \\
\hline $\mathrm{MgHA}^{+}$ & 3.67 & {$[7]$} & $\mathrm{CuFA}^{0}$ & 7.85 & {$[7]$} & $\mathrm{PbFA}^{0}$ & 4.10 & {$[5]$} \\
\hline $\mathrm{MnFA}^{0}$ & 4.17 & {$[7]$} & $\mathrm{Cu}(\mathrm{OH})_{2} \mathrm{FA}^{2-}$ & 7.74 & {$[5]$} & $\left.\mathrm{Pb}^{2} \mathrm{HA}\right)_{2}{ }^{0}$ & 8.70 & {$[9]$} \\
\hline $\mathrm{MnHA}^{+}$ & 4.58 & {$[7]$} & $\mathrm{CuHA}$ & 6.20 & {$[8]$} & $\mathrm{PbHA}^{+}$ & 6.53 & {$[8]$} \\
\hline $\mathrm{AlFA}^{+}$ & 6.46 & {$[10]$} & $\mathrm{Cu}(\mathrm{HA})_{2}{ }^{0}$ & 8.90 & {$[9]$} & $\mathrm{UO}_{2} \mathrm{FA}^{0}$ & 4.54 & {$[11]$} \\
\hline $\mathrm{FeFA}^{0}$ & 4.67 & {$[5]$} & $\mathrm{ZnFA}^{0}$ & 4.83 & {$[7]$} & $\mathrm{UO}_{2}\left(\mathrm{FA}_{2}{ }^{2-}\right.$ & 7.45 & {$[11]$} \\
\hline $\mathrm{FeFA}$ & 7.00 & {$[5]$} & $\mathrm{ZnHA}^{+}$ & 5.19 & {$[7]$} & $\mathrm{UO}_{2} \mathrm{HA}^{+}$ & 5.38 & {$[11]$} \\
\hline $\mathrm{FeOHFA}$ & 19.50 & {$[12]$} & $\mathrm{MoO}_{2} \mathrm{HA}^{+}$ & 12.90 & {$[13]$} & $\mathrm{UO}_{2}\left(\mathrm{HA}_{2}{ }_{2}{ }^{0}\right.$ & 9.59 & {$[11]$} \\
\hline $\mathrm{Fe}(\mathrm{OH})_{2} \mathrm{FA}^{-}$ & 29.41 & {$[12]$} & $\mathrm{MoO}_{2}\left(\mathrm{HA}_{2}{ }_{2}{ }^{0}\right.$ & 6.90 & {$[13]$} & & & \\
\hline
\end{tabular}

The thermodynamic model consisted of $\mathrm{Al}, \mathrm{C}, \mathrm{Ca}, \mathrm{Cd}, \mathrm{Cl}, \mathrm{Co}, \mathrm{Cu}, \mathrm{FA}$ (fulvic acid), $\mathrm{Fe}$, $\mathrm{H}$, HA (humic acid), K, Mg, Mn, Mo, N, Na, O, Pb, S, Si, U, W, Zn. Trace elements were chosen based on comparing their concentration in studied water with the background concentrations in the Poyang Lake area's surface water and the world average concentrations for river water. The following ions and components were included in the system as basic (components which are used for water chemistry description): $\mathrm{H}_{2} \mathrm{O}, \mathrm{O}_{2}(\mathrm{aq}), \mathrm{CO}_{2}(\mathrm{aq}), \mathrm{HCO}_{3}{ }^{-}$ , $\mathrm{SO}_{4}{ }^{2-}, \mathrm{NO}_{2}{ }^{-}, \mathrm{NO}_{3}{ }^{-}, \mathrm{Cl}^{-}, \mathrm{Ca}^{2+}, \mathrm{Mg}^{2+}, \mathrm{Na}^{+}, \mathrm{K}^{+}, \mathrm{NH}_{4}{ }^{+}, \mathrm{FA}^{2-}, \mathrm{HA}^{-}, \mathrm{SiO}_{2}(\mathrm{aq}), \mathrm{Al}^{3+}, \mathrm{Fe}^{2+}, \mathrm{Mn}^{2+}$, $\mathrm{Co}^{2+}, \mathrm{Cu}^{2+}, \mathrm{Zn}^{2+}, \mathrm{MoO}_{4}^{2-}, \mathrm{Cd}^{2+}, \mathrm{WO}_{4}{ }^{2-}, \mathrm{Pb}^{2+}, \mathrm{U}^{4+}$. The model included more than a hundred associates (derived from basic components) in addition to the basic components. Secondary mineral precipitation from the studied water was simulated together with the calculation of migration forms. The model included the following minerals: boehmite, calcite, chlorite, dolomite, gibbsite, goethite, illite, kaolinite, montmorillonite ( $\mathrm{Ca}, \mathrm{Mg}, \mathrm{Na}, \mathrm{K}$ ), which were chosen relying on the mineral composition of the upper part of the rice field soil horizon and wetland bottom sediments.

\section{Results and Discussion}

The chemical composition of irrigation water generally corresponds to the shallow groundwater composition in the Poyang Lake area, including relatively high concentrations of typical pollutants such as $\mathrm{K}^{+}, \mathrm{Cl}^{-}$, and $\mathrm{SO}_{4}{ }^{2-}$ [14]. Ion $\mathrm{Ca}^{2+}$ predominates in its cationic 
composition. The anionic composition is heterogeneous. The values of TDS correspond to fresh (up to $500 \mathrm{mg} / \mathrm{L}$ ). According to the $\mathrm{pH}$ value, water is slightly acidic. The water of natural wetland is characterized by lower TDS values (up to $100 \mathrm{mg} / \mathrm{L}$ ) and slightly lower $\mathrm{pH}$ values that are confirmed by modeling data. According to the major physicochemical parameters, natural wetland water is closer to the river water of the study area [15].

Modeling the aqueous migration in the $\mathrm{HCh}$ has shown that the main cations $(\mathrm{Ca}, \mathrm{Mg}$, $\mathrm{Na}, \mathrm{K}$ ) related to alkali and alkaline earth metals migrate as simple ions (Fig. 2). This behavior is typical for natural water. With an increase of TDS value, a complexation with $\mathrm{Cl}^{-}$ and $\mathrm{SO}_{4}{ }^{2-}$. Most of the considered transition metals $(\mathrm{Mn}, \mathrm{Co}, \mathrm{Cu}, \mathrm{Zn}, \mathrm{Cd}, \mathrm{Pb})$ also migrate as simple ions. It should be highlighted that although $\mathrm{Cu}, \mathrm{Zn}$, and $\mathrm{Pb}$ tend to migrate as simple ions, the changes in $\mathrm{pH}$ values lead to a rise in the content of complexes with hydroxide and carbonate ligands. For the rest of the metals mentioned above, this is also fair but less markedly. As for Mo and $\mathrm{W}$, they migrate as $\mathrm{MoO}_{4}{ }^{2-}$ and $\mathrm{WO}_{4}{ }^{2-}$ with a slight increase of $\mathrm{HMoO}_{4}{ }^{-}$and $\mathrm{HWO}_{4}{ }^{-}$under lower $\mathrm{pH}$ values.
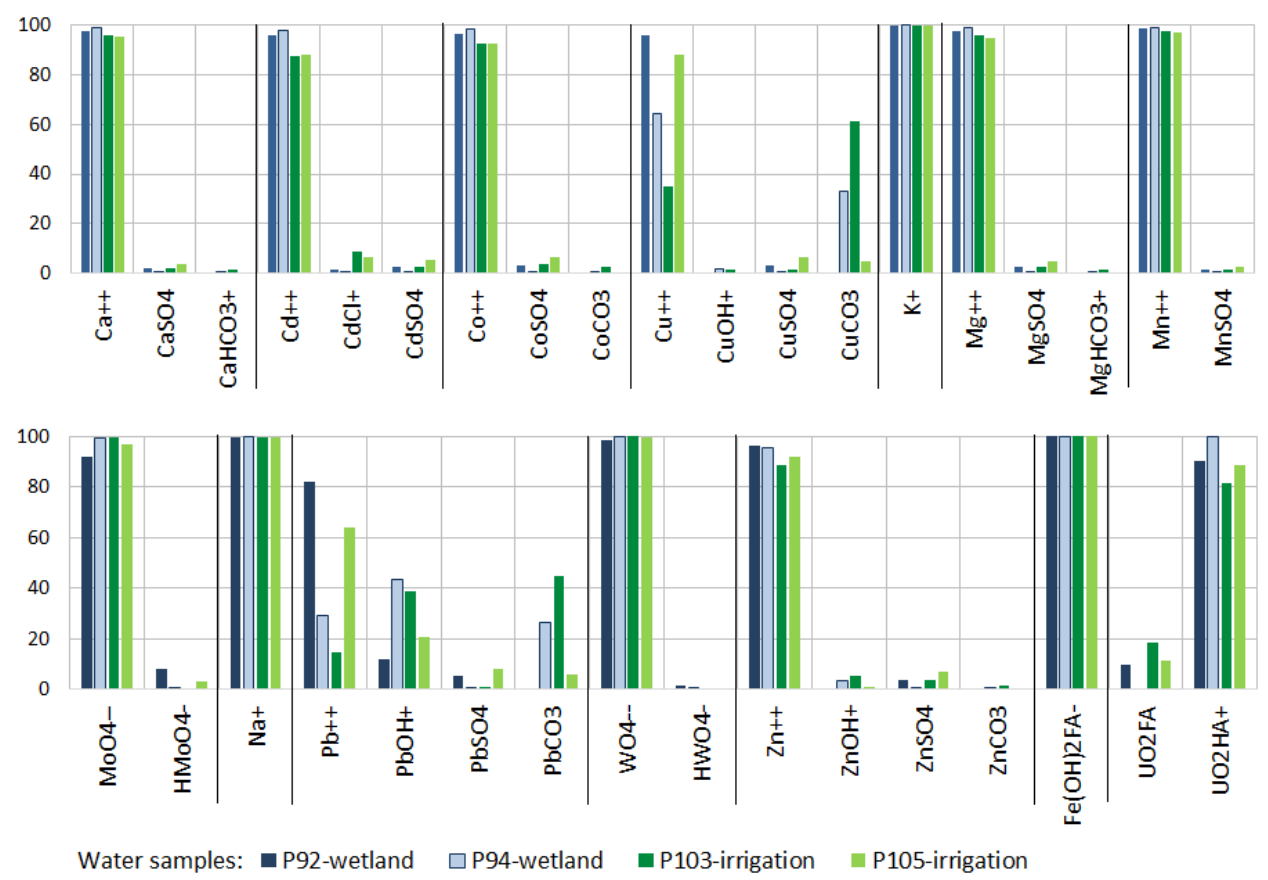

Fig. 2. Predominant migration forms of metals in irrigation water, mol\% (the total molal concentration of all migration forms of each metal is equal to 100 mol.\%; only migration forms with concentration more than 1 mol\% are given)

According to the modeling results, the behavior of $\mathrm{Fe}$ and $\mathrm{U}$ strongly depends on $\mathrm{FA}$ and HA content. Fulvic acid binds almost all Fe, while $\mathrm{U}$ has a higher affinity to humic acid (Fig. 2). Affinity to humic substances (both FA and HA) characterizes Ca behavior (Table 2). Thus, the distribution of FA in the studied objects depends on the concentration of Fe and Ca. In the sampling point P94, Fe binds all FA under the concentration of $0.28 \mathrm{mg} / \mathrm{L}$. Distribution of HA connected with $\mathrm{Ca}$ and $\mathrm{U}$. Most of HA is bound by $\mathrm{Ca}$, probably due to the low concentration of $U$ in the studied water and the higher affinity of $\mathrm{Ca}$ to HA. However, some authors confirm that $U$ complexes with humic substances are unstable [16]; therefore, sorption of $\mathrm{UO}_{2}{ }^{2+}$ can occur in the studied objects as a possible mechanism of $\mathrm{U}$ immobilization in aerobic conditions. 
Table 2. Distribution of organomineral complexes in the studied water, mol\%

\begin{tabular}{|l|r|r|r|r|}
\hline \multirow{2}{*}{$\begin{array}{c}\text { Organomineral } \\
\text { complex }\end{array}$} & \multicolumn{2}{c|}{ Wetland water } & \multicolumn{2}{c|}{ Irrigation water } \\
\cline { 2 - 5 } & P92 & P94 & P103 & P105 \\
\hline \multicolumn{3}{|c|}{ Me-FA complexes (assumed that equal to100 mol\% in total) } \\
\hline $\mathrm{CaFA}^{0}$ & 43.81 & $5.33 \mathrm{E}-23$ & 87.80 & 51.06 \\
\hline $\mathrm{Fe}(\mathrm{OH})_{2} \mathrm{FA}^{-}$ & 56.19 & $\sim 100.00$ & 12.20 & 48.94 \\
\hline $\mathrm{UO}_{2} \mathrm{FA}^{0}$ & $8.72 \mathrm{E}-04$ & $8.65 \mathrm{E}-28$ & $4.51 \mathrm{E}-03$ & $4.06 \mathrm{E}-04$ \\
\hline Me-HA complexes (assumed that equal to 100 mol\% in total) \\
\hline $\mathrm{CaHA}^{+}$ & 98.88 & 99.08 & 97.16 & 99.55 \\
\hline $\mathrm{UO}_{2} \mathrm{HA}^{+}$ & 1.12 & 0.92 & 2.84 & 0.45 \\
\hline
\end{tabular}

According to the modeling results, kaolinite potentially can precipitate from irrigation water (up to 5.74E-7 mol). In the upper part of the studied soil horizons, kaolinite is one of the main clay minerals. In natural wetland water, goethite potentially precipitates along with kaolinite in the P94 sampling point characterized by the highest Fe content.

\section{Conclusion}

Thermodynamic modeling has shown that most of the considered chemical elements migrate as positively charged simple ions in the water under study. The main agents of complexation with humic substances are Fe, Ca, and U. Developing a model of sorption, special attention should be paid to sorption of positively charged simple ions on clay minerals (especially kaolinite). Adsorption of $\mathrm{MoO}_{4}{ }^{2-}$ should also be considered as Mo is an important element for the nitrogen cycle as a part of the nitrogenase enzyme, and some clay minerals tend to sorb it [17].

\section{Acknowledgments}

The authors thank colleagues Yihui Dong, Jiale Li, and Irina Ivanova, who helped with the fieldwork organization and conduction. We are also thankful to Andrey Toropov, Irina Gromyak, and Denis Dogadkin, who analyze water samples. Great thanks to Elena Cherkasova for helping with searching for the stability constants. The research is funded by the Russian Science Foundation, project No 19-77-00014.

\section{References}

1. O. Savichev, E. Soldatova, M. Rudmin, A. Mazurov, Appl. Geochemistry, 113, 104519 (2020)

2. I.S. Ivanova, O.G. Savichev, E.A. Soldatova et al., Bull. Tomsk Polytech. Univ. Geo Assets Eng., 331(3), 39-51 (2020) In Rus

3. S.R. Krainov, Y.V. Shvarov, D.V. Grichuk et al., Methods of geochemical modeling and forecasting in hydrogeology (Nedra, Moscow, 1988) In Rus

4. Y.V. Shvarov, Geochemistry Int., 46(8), 898-903 (2008)

5. G.M. Varshal, Formy migratsii fulvokislot i metallov v prirodnyh vodah, Abstract of Doctoral Thesis, Vernadsky Institute of Geochemistry and Analytical Chemistry RAS (Moscow, 1994) In Rus

6. Y.Yamamoto, F. Kita, N. Isono, S. Imai, Bunseki kagaku, 66(12), 875-883 (2017) 
7. R.F.C. Mantoura, A. Dickson, J. P. Riley, Estuar. Coast. Mar. Sci., 6(4), 387-408, (1978)

8. R.D. Guy, C.L. Chakrabarti, Can. J. Chem., 54(16), 2600-2611 (1976)

9. F. J. Stevenson, Soil Sci. Soc. Am. J., 40 (5), 665-672 (1976)

10. K.M. Elkins, D.J. Nelson, J. Inorganic Biochem., 87(1), 81-96 (2001)

11. J. . Lenhart, S.E. Cabaniss, P. MacCarthy, B.D. Honeyman, Radiochim. Acta, 88(6), 345-353 (2000)

12. O.A. Lipatnikova, D.V. Grichuk, Vestn. Mosk. Univ. Seriya 4. Geol., 2, 51-59 (2001) In Rus

13. A.L.R. Mercê, P.P. Lopes, A.S. Mangrich, N.M. Levy, J. Braz. Chem. Soc., 17(3), 482490 (2006)

14. E. Soldatova, Z. Sun, S. Maier, V. Drebot, B. Gao, Environ. Geochem. Health, 40(5), 2223-2242 (2018)

15. E.A. Soldatova, N.V. Guseva, Z. Sun, I. S. Mazurova, IOP Conference Series: Earth and Environmental Science, 27(1), 012037 (2015)

16. J. Liao, W. Wen, B. Li et al., Nucl. Sci. Tech., 24(3), 030301 (2013)

17. J. P. Gustafsson, C. Tiberg, Chem. Geol., 417, 279-288 (2015) 